\title{
Antiviral meroterpenoid rhodatin and sesquiterpenoids rhodocoranes A-E from the wrinkled peach mushroom, Rhodotus palmatus
}

\author{
BIRTHE SANDARGO ${ }^{\dagger}$; MAIRA MICHEHL ${ }^{\dagger}, \mid$; DIMAS PRADITYA ${ }^{ \pm \dagger}$, EIKE STEINMANN $^{ \pm, \mid}$, MARC \\ STADLER $^{\dagger} \&$ FRANK SURUP ${ }^{\dagger *}$. \\ ${ }^{\dagger}$ Department of Microbial Drugs, Helmholtz Centre for Infection Research GmbH, Inhoffenstraße 7, 38124 Braunschweig, \\ Germany and German Centre for Infection Research (DZIF), partner site Hannover-Braunschweig, 38124 Braunschweig, \\ Germany.
}

${ }^{ \pm}$TWINCORE-Centre for Experimental and Clinical Infection Research (Institute of Experimental Virology), Feodor-LynenStr. 7-9, 30625 Hannover, Germany.

${ }^{\ddagger}$ Research Center for Biotechnology, Indonesian Institute of Science, Jl. Raya Bogor KM 46, Cibinong, Indonesia.

' Department of Molecular and Medical Virology, Ruhr-University Bochum, 44801 Bochum, Germany.

Supporting Information
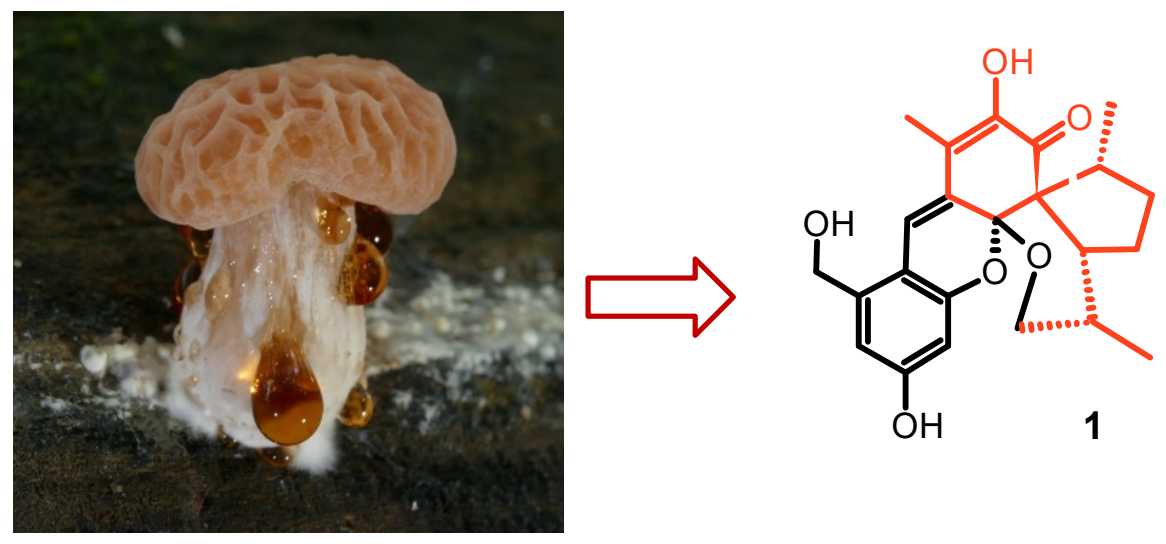

\begin{abstract}
Rhodatin (1), a meroterpenoid featuring an unique pentacyclic scaffold with both spiro and spiroketal centers, plus five unusual acorane-type sesquiterpenoids, named rhodocoranes A-E (2-6), are the first natural products isolated from the basidiomycete Rhodotus palmatus. Their structures were elucidated by 2D NMR experiments and HRESIMS, while the absolute configuration of the substance family was determined by Mosher's method utilizing $\mathbf{2}$. Rhodatin exhibited strong inhibition of hepatitis C virus, whereas $\mathbf{4}$ displayed cytotoxicity and selective antifungal activity.
\end{abstract}

The wrinkled peach mushroom, Rhodotus palmatus (Bull.) Maire, also known as rosy veincap, is every mycologist's delight. Conspicuous pink caps with deep engravings and large, blood-like drops covering young fruiting bodies give this rarely found mushroom its unique appearance. Possessing a circumboreal distribution ${ }^{1}$, it is a pioneer fungus on relatively fresh rotting hardwoods only, with a preference for elm trees ${ }^{2}$. Due to its scarcity, and the fact that it is considered an endangered species in many countries, ${ }^{3}$ relatively little is known about this mushroom, in particular when it comes to its secondary metabolites. A 2000 study, screening several hundred
Basidiomycota, however, ascribed the fungus a general antimicrobial activity ${ }^{4}$. Prompted by a recent finding in Germany, we cultivated this unusual basidiomycete and isolated the very first natural products. We herein present the isolation, structure elucidation and biological evaluation of an auspicious candidate in targeting viral hepatitis infection: rhodatin (1), alongside five unprecedented, novel sesquiterpenoids, rhodocoranes A-E (2-6) with cytotoxic and antimicrobial activity.

Rhodatin (1) was isolated as a bright yellow oil. Its molecular formula of $\mathrm{C}_{23} \mathrm{H}_{26} \mathrm{O}_{6}$ was established from a molecular ion cluster at $m / z$ 399.1806 $[\mathrm{M}+\mathrm{H}]^{+}$(calcd for $\mathrm{C}_{23} \mathrm{H}_{27} \mathrm{O}_{6} 399.1808$ ) 
in the HRESIMS spectrum, implying 11 degrees of unsaturation. Analysis of the ${ }^{1} \mathrm{H}$ NMR data (Table 1) revealed three methyls at $\delta_{\mathrm{H}} 0.75$ (d, H-14), 0.80 (d, H-13), 2.05 (s, $\left.\mathrm{H}_{3}-15\right)$, two methylenes at $\delta_{\mathrm{H}} 1.56$ (ddd, $\left.\mathrm{H}-2\right), 1.99$ (m, H-2), 1.77 (m, $\mathrm{H}-3)$, and 2.19 (m, H-3), and two oxygenated methylenes at $\delta_{\mathrm{H}} 3.12$ (dd, H-12), 3.50 (t, H-12), 4.55 (dd, H-23'), and 4.62 (dd, H-23”). The ${ }^{13} \mathrm{C}$ NMR (Table 1 ) and HSQC-

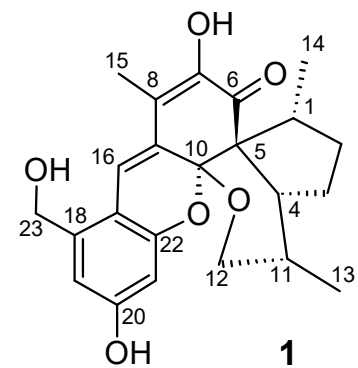

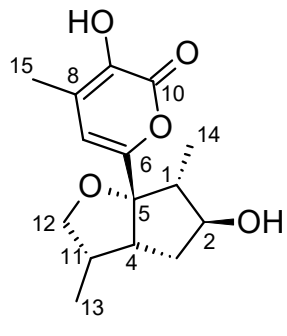<smiles>CC1=C(O)C(=O)C2(C(=O)C(C)C)[C@H](C)CC[C@H]2C1O</smiles>

3<smiles>CC1=C(N)C(=O)[C@]2(C(=O)C1=O)[C@H](C)CC[C@@H]2C(C)C</smiles>

5<smiles>CC1=CC(=O)[C@]2(C(=O)C1=O)[C@H](C)CC[C@@H]2C(C)C</smiles><smiles>CC1=C(O)C(=O)[C@]2(C(=O)C1=O)[C@H](C)CC[C@@H]2C(C)C</smiles>

6

Figure 1. Chemical structures of rhodocoranes A-E (2-6).

dept data show the presence of 23 carbon resonances, comprising one carbonyl carbon $\left(\delta_{C} 193.2, C-6\right)$, ten $\mathrm{sp}^{2}$-hybridized carbons, including three aromatic carbons, of which two are oxygenated ( $\delta_{\mathrm{C}}$ 158.6, C-20 and 150.1, C-22) and three $\mathrm{sp}^{2}$ hybridized methines $\left(\delta_{\mathrm{C}} 101.9\right.$, C-21; 109.2 , C-19; $116.8, \mathrm{C}-$ $16)$; two quaternary carbons, including one highly oxygenated carbon $\left(\delta_{\mathrm{C}} 96.2\right.$, C-10), three methines $\left(\delta_{\mathrm{C}} 28.3\right.$, C-11; 44.2, $\mathrm{C}-4$; 46.3, C-1); two oxygenated methylene carbons $\left(\delta_{\mathrm{C}} 60.5\right.$, C-12 and 60.3, C-23), and two methylenes at $\delta_{\mathrm{C}} 22.9$ (C-3) and 32.7 (C-2); as well as three methyl carbons $\left(\delta_{\mathrm{C}} 10.8\right.$, C$15 ; 14.4, \mathrm{C}-13 ; 14.5, \mathrm{C}-4)$. The carbonyl and $\mathrm{sp}^{2}$-hybridized carbons indicate six degrees of unsaturation, requiring five rings in the scaffold of rhodatin (1). The planar structure was elucidated by extensive analysis of the 2D NMR experiments. ${ }^{1} \mathrm{H}-{ }^{1} \mathrm{H}$ COSY and TOCSY data (Figure 2) quickly established the $\mathrm{H}_{3}-14 / \mathrm{H}-1 / \mathrm{H}_{2}-2-/ \mathrm{H}_{2}-3 / \mathrm{H}-4 / \mathrm{H}-11 / \mathrm{H}_{3}-12 / \mathrm{H}_{3}-13$ spin system. HMBC correlations (Figure 2), especially those from $\mathrm{H}_{2}-$ 23 to $\mathrm{C}-17 / \mathrm{C}-18 / \mathrm{C}-19$, from $\mathrm{H}-21$ to $\mathrm{C}-17 / \mathrm{C}-19$, from $\mathrm{H}-16$ to $\mathrm{C}-8 / \mathrm{C}-10 / \mathrm{C}-18 / \mathrm{C}-22$, from $\mathrm{H}_{3}-15$ to $\mathrm{C}-7 / \mathrm{C}-8 / \mathrm{C}-9$ and $\mathrm{H}-$ 1 to $\mathrm{C}-5 / \mathrm{C}-6 / \mathrm{C}-10$, established the constitution of the carbon backbone, with the exception of $\mathrm{C}-6$ and $\mathrm{C}-7$ being loose ends. In order to connect these, an HSQMBC ${ }^{5}$ was measured as well as an HMBC with an elongated long range delay optimized for C,H-coupling constants $J$ of $2 \mathrm{~Hz}$, which allow ultra-range ${ }^{4} J$ and occasionally ${ }^{5} J$ and ${ }^{6} J$ couplings to be visible. These data showed correlations of $\mathrm{H}-16$ to $\mathrm{C}-5\left({ }^{4} \mathrm{~J}\right), \mathrm{C}-7\left({ }^{4} \mathrm{~J}\right)$

and C-6 $\left({ }^{5} \mathrm{~J}\right)$, setting a cyclohexenone moiety in place and giving rise to the novel pentacyclic scaffold of rhodatin (1).

Table 1. ${ }^{1} \mathrm{H}(700 \mathrm{MHz})$ and ${ }^{13} \mathrm{C}(176 \mathrm{MHz})$ NMR data of $\mathbf{1}$ in DMSO- $d_{6}$.

\begin{tabular}{|c|c|c|}
\hline \multirow[b]{2}{*}{ position } & \multicolumn{2}{|r|}{1} \\
\hline & $\delta_{\mathrm{C}}$ & $\delta_{\mathrm{H}}(J$ in $\mathrm{Hz})$ \\
\hline 1 & 46.3, $\mathrm{CH}$ & 1.91, m \\
\hline $2 \alpha$ & $32.7, \mathrm{CH}_{2}$ & 1.99, m \\
\hline $2 \beta$ & & 1.56, ddd $(15.7,12.2,3.8)$ \\
\hline $3 \alpha$ & 22.9, $\mathrm{CH}_{2}$ & $1.77, \mathrm{~m}$ \\
\hline $3 \beta$ & & $2.19, \mathrm{~m}$ \\
\hline 4 & 44.2, $\mathrm{CH}$ & 3.07, td $(8.6,4.7)$ \\
\hline 5 & $59.8, \mathrm{C}_{\mathrm{q}}$ & \\
\hline 6 & $193.2, \mathrm{C}_{\mathrm{q}}$ & \\
\hline 7 & $144.6, \mathrm{C}_{\mathrm{q}}$ & \\
\hline 8 & $125.0, \mathrm{C}_{\mathrm{q}}$ & \\
\hline 9 & $127.6, \mathrm{C}_{\mathrm{q}}$ & \\
\hline 10 & $96.2, \mathrm{C}_{\mathrm{q}}$ & \\
\hline 11 & 28.3, CH & $1.68, \operatorname{td}(12.2,5.3)$ \\
\hline $12 \alpha$ & $60.5, \mathrm{CH}_{2}$ & 3.12, dd $(11.3,5.0)$ \\
\hline $12 \beta$ & & $3.50, \mathrm{t}(11.3)$ \\
\hline 13 & $14.4, \mathrm{CH}_{3}$ & $0.80, \mathrm{~d}(6.9)$ \\
\hline 14 & 14.5, $\mathrm{CH}_{3}$ & $0.75, \mathrm{~d}(6.6)$ \\
\hline 15 & $10.8, \mathrm{CH}_{3}$ & $2.05, \mathrm{~s}$ \\
\hline 16 & 116.8, CH & $6.88, \mathrm{~s}$ \\
\hline 17 & 111.2, C & \\
\hline 18 & $140.0, \mathrm{C}_{\mathrm{q}}$ & \\
\hline 19 & 109.2, CH & $6.58, \mathrm{~d}(2.4)$ \\
\hline 20 & $158.6, \mathrm{C}_{\mathrm{q}}$ & \\
\hline 21 & 101.9, CH & $6.35, \mathrm{~d}(2.3)$ \\
\hline 22 & $150.1, \mathrm{C}_{\mathrm{q}}$ & \\
\hline $23^{\prime}$ & $60.3, \mathrm{CH}_{2}$ & 4.55, dd $(13.7,4.7)$ \\
\hline $23 "$ & & 4.62, dd $(13.7,4.7)$ \\
\hline $23-\mathrm{OH}$ & & $5.20, \mathrm{t}(5.1)$ \\
\hline
\end{tabular}

The relative configuration was deduced from ROE data (Figure 3). Key correlations between $\mathrm{H}-1, \mathrm{H}-2 \alpha, \mathrm{H}-3 \alpha, \mathrm{H}-4$ and $\mathrm{H}-11$ showed these to be co-facial and were therefore arbitrarily assigned $\alpha$-orientation. Strong ROE correlations between $\mathrm{H}-11$ and $\mathrm{H}-4$ in addition to those between $\mathrm{H}_{3}-13$ and $\mathrm{H}-3$ define $\mathrm{C}-11$. Correlations between $\mathrm{H}-21$ to $\mathrm{H}-2 \beta, \mathrm{H}-3 \beta$ and $\mathrm{H}-12 \beta$ as well as $\mathrm{H}-16$ and $\mathrm{H}-15$ to $\mathrm{H}-14$ define the relative configuration of $\mathrm{C}-5$. Finally, the absolute configuration of rhodatin (1) was determined as $1 R, 4 R, 5 R, 10 R, 11 S$ through Mosher esterification of $\mathbf{2}$ at position $\mathrm{C}-2$. 


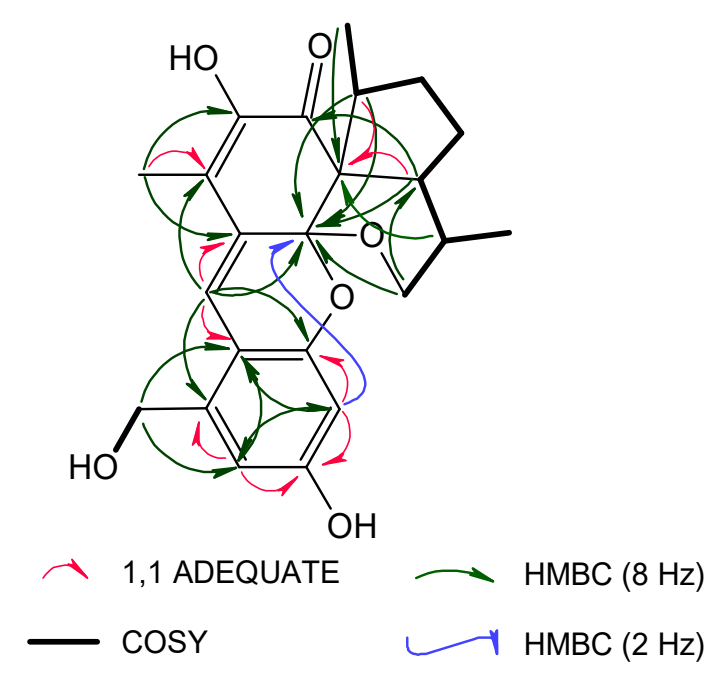

Figure 2. Key HMBC, COSY, and 1,1 ADEQUATE correlations.

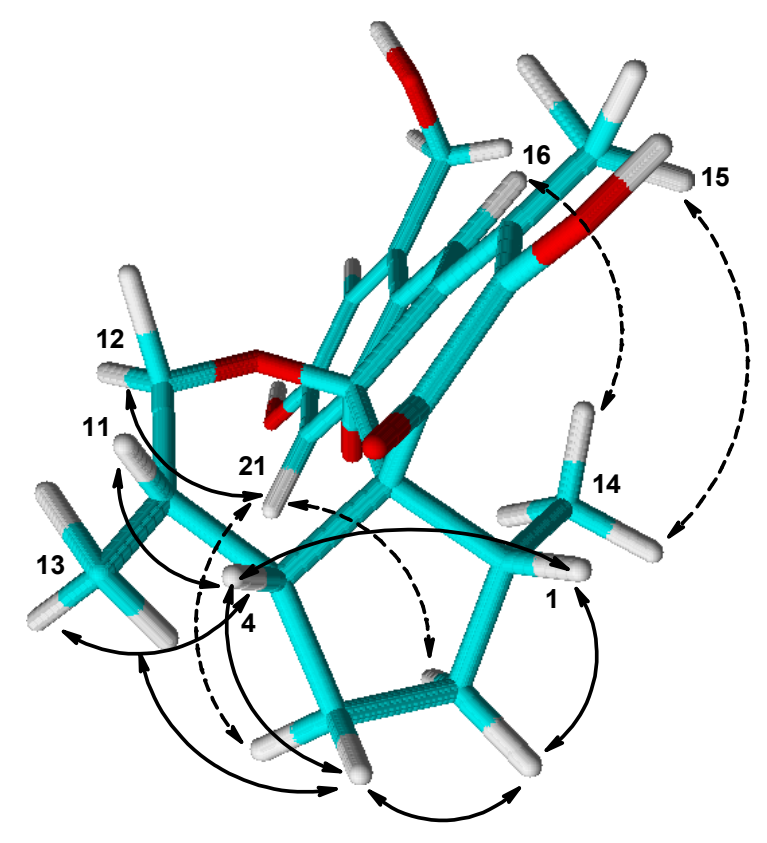

Figure 3. Key ROE correlations of rhodatin (1). Correlations above the molecular main plane are indicated with solid arrows, correlations below dashed.

Rhodocorane A (2) was isolated as a brown oil, with a molecular formula of $\mathrm{C}_{15} \mathrm{H}_{20} \mathrm{O}_{5}$, based on HRESIMS analysis. ${ }^{1} \mathrm{H}$ and ${ }^{13} \mathrm{C}$ NMR data of $\mathbf{2}$ (Table S6) showed slight similarity to $\mathbf{I}$ and after analysis of ${ }^{1} \mathrm{H},{ }^{1} \mathrm{H}$ COSY data (Figure S1) the isopropyl-methyl-cyclopentane moiety was quickly established and revealed an additional hydroxy function at $\mathrm{C}-2\left(\delta_{\mathrm{C}}\right.$ 78.7). However, analysis of HMBC data (Fig. S1) also display a strong ${ }^{3} J$ correlation between $\mathrm{H}-12\left(\delta_{\mathrm{H}} 4.05\right)$ and $\mathrm{C}-5\left(\delta_{\mathrm{C}}\right.$ 93.4), indicating a ring closure. HMBC correlations further established an 8-methyl $\left(\delta_{\mathrm{C}} 12.1\right)$ 9-hydroxy pyranone moiety linked to $\mathrm{C}-5$ at position C-6 $\left(\delta_{\mathrm{C}} 161.6\right)$, resulting in a novel cyclopentafuranyl-pyranone scaffold. Key ROESY interactions (Figure S2) are $\mathrm{H}-1 / \mathrm{H}-4, \mathrm{H}-4 / \mathrm{H}-11$, and $\mathrm{H}-2 / \mathrm{H}_{3}-12$, requiring $\mathrm{H}-1, \mathrm{H}-3 \alpha, \mathrm{H}-4$, and $\mathrm{H}-11$ in $\alpha$-orientation. Sterically, this only allows the oxygen at $\mathrm{C}-5$ facing in $\beta$-orientation. The absolute configuration was assigned by the modified Mosher's method $^{6}$. Based on the positive $\Delta \delta^{S R}$ values of $\mathrm{H}-1$ and $\mathrm{H}_{3}-14$ and the negative ones of $\mathrm{H}_{2}-3, \mathrm{H}-4, \mathrm{H}-11$ and $\mathrm{H}_{3}-13$ (Table $\mathrm{S} 2$, Supporting Information) the absolute $1 R, 2 S, 4 R, 5 S, 11 S$ configuration was assigned for rhodocorane A (2).

Rhodocorane $\mathrm{B}(\mathbf{3})$, was isolated as a white powder with the molecular formula of $\mathrm{C}_{15} \mathrm{H}_{22} \mathrm{O}_{4}$. Analyzing the $1 \mathrm{D}$ and $2 \mathrm{D}$ NMR data (Supporting Information) of $\mathbf{3}$, the 1-methyl, 4-(1methylethyl) cyclopentane skeleton can easily be identified. $\mathrm{H}-1\left(\delta_{\mathrm{C}} 51.6\right)$ and $\mathrm{H}-4\left(\delta_{\mathrm{C}} 56.3\right)$ show HMBC correlations to $\delta_{\mathrm{C}} 74.8(\mathrm{C}-10)$ and $199.7(\mathrm{C}-6)$. In combination with HMBC correlations of $\mathrm{H}-15\left(\delta_{\mathrm{H}} 1.95\right)$ and $\mathrm{H}-10\left(\delta_{\mathrm{H}} 4.58\right)$ a 7 -cyclohexene-6,9-dione 7,10-dihydroxy, 8-methyl was determined, leading to an acorane type sesquiterpenoid. The relative configuration was determined by ROE correlations. In particular those between $\mathrm{H}-4$ and $\mathrm{H}-1$ / $\mathrm{H}-11$ confirmed the $1 R, 4 R$ configuration of the cyclopentyl substructure in common with $\mathbf{I}$ and 2. The ROESY correlation between $\mathrm{H}-10$ and $\mathrm{H}-11 / \mathrm{H}_{3}-$ 12 defined the 5S,10S configuration (Figure S3). The absolute configuration is deduced from comparison to $\mathbf{2}$, as $1 R, 4 R, 5 S, 10 S$ 7,10-dihydroxy-8-methylcyclohexen-6,9-dione.

Closely related to $\mathbf{3}$ is the brown oil, rhodocorane $\mathrm{C}(\boldsymbol{4})$. Possessing a molecular formula of $\mathrm{C}_{15} \mathrm{H}_{20} \mathrm{O}_{3}$ its ${ }^{1} \mathrm{H}$ and ${ }^{13} \mathrm{C}$ NMR data (Table S8) largely resemble those of 3. They only differ in the existence of a sp ${ }^{2}$ hybridized methine at C-9 $\left(\delta_{\mathrm{C}}\right.$ $143.8)$ and the replacement of the hydroxyl by carbonyl functionalities, at $\mathrm{C}-7\left(\delta_{\mathrm{C}} 182.1\right)$ and $\mathrm{C}-10\left(\delta_{\mathrm{C}} 198.1\right)$. Interproton distance correlations of the cyclopentane moiety are identical to those of 3. ROESY interactions of $\mathrm{H}-9\left(\delta_{\mathrm{H}} 6.99\right)$ with $\mathrm{H}-12$ $\left(\delta_{\mathrm{H}} 0.55\right)$ and $\mathrm{H}-14\left(\delta_{\mathrm{H}} 0.85\right)$ were observed, implying $\mathbf{4}$ has the same configuration as rhodocorane $\mathrm{B}(\mathbf{3})$.

Rhodocoranes D (5) and E (6) only differ from $\mathbf{4}$ by the substitution at C-9. While $\mathbf{5}$ features an amino group at C-9 ( $\delta_{\mathrm{C}}$ 154.8), confirmed by ${ }^{1} \mathrm{H},{ }^{15} \mathrm{~N}$ HSQC data, rhodocorane $\mathrm{F}$ (6) contains a hydroxy group at C-9 $\left(\delta_{C} 171.9\right)$. ROE correlations of both are consistent with those of $\mathbf{4}$, suggesting the same relative configuration. To ratify the absolute configuration of $1 R, 4 R, 5 S$, and due to a lack of protons in the cyclohexenone part, CD spectra were recorded (Figure S5) and are in close agreement with $\mathbf{4}$, confirming the common absolute configuration.

On a closer look, the acorane-like structural moiety can be identified in all metabolites including 1 (highlighted in red) suggesting a common biosynthetic origin. The biosynthesis of acorane type sesquiterpenoids in fungi, particularly Trichoderma (Ascomycota), was closely investigated by feeding deuterated mevalonolactone isotopomers. ${ }^{7}$ However, the true biosynthetic pathway of $\mathbf{I}$ remains obscure. The pentacyclic structure of rhodatin (1) appears to be of mixed biosynthetic origin, likely orcinalydehyde is connected to an acorane type precursor, as it has been reported in other cases for fungal metabolites $^{8}$ (see Figure S6, for a proposed biosynthesis scheme). This is in contrast to the proposed biosynthesis of paranolin from a xanthone core, despite their close structural similatity (Figure S1). ${ }^{9}$

Rhodatin (1) was next evaluated for antiviral activity against hepatitis $\mathrm{C}$ virus (HCV) in human liver cells. With deaths due to viral hepatitis infections being on the rise worldwide $^{10}$, the world health assembly has set the objective to eradicate viral hepatitis by $2030 .{ }^{11}$ Viral infectivity was inhibited in a dose-dependent manner with an $\mathrm{IC}_{50}$ value of $9.5 \mu \mathrm{M}$ and strong inhibitory effect at $40 \mu \mathrm{M}$ without any effect on cell viability, which was evaluated simultaneously (Fig. 4). The 
green tea molecule EGCG was used as positive control. ${ }^{12,13}$ Its lack of cytotoxicity and devoid antibacterial activity make rhodatin (1) a promising candidate for further evaluation against HCV infections.

Rhodocoranes A-E (2-6) showed diverse cytotoxic and antibiotic effects. Notably, rhodocorane C (4) showed the strongest cytotoxic effects against the carcinoma cell lines KB3.1 (cervix carcinoma), MCF-7 (human adenocarcinoma), A431 (human epidermoid carcinoma) with $\mathrm{IC}_{50}$ values ranging between 1.3-5.6 $\mu \mathrm{M}$ (see Table S3). 4 also exhibited potent, selective activity against various fungi (Table S4), like for example the plant pathogen Nematospora coryli DSM 6981 (MIC = $2 \mu \mathrm{M}$ ), or the upcoming pathogen Rhodotorula glutinis DSM 10134 (MIC $=8.5 \mu \mathrm{M})$. Many yeasts, like Rhodotorula glutinis are highly drug-resistant ${ }^{14}$, yet emerging as opportunistic pathogens causing in particular fungemia in immunosuppressed patients. ${ }^{15}$ Novel cytotoxic drugs with selective antifungal activity will therefore be of great demand in the future.

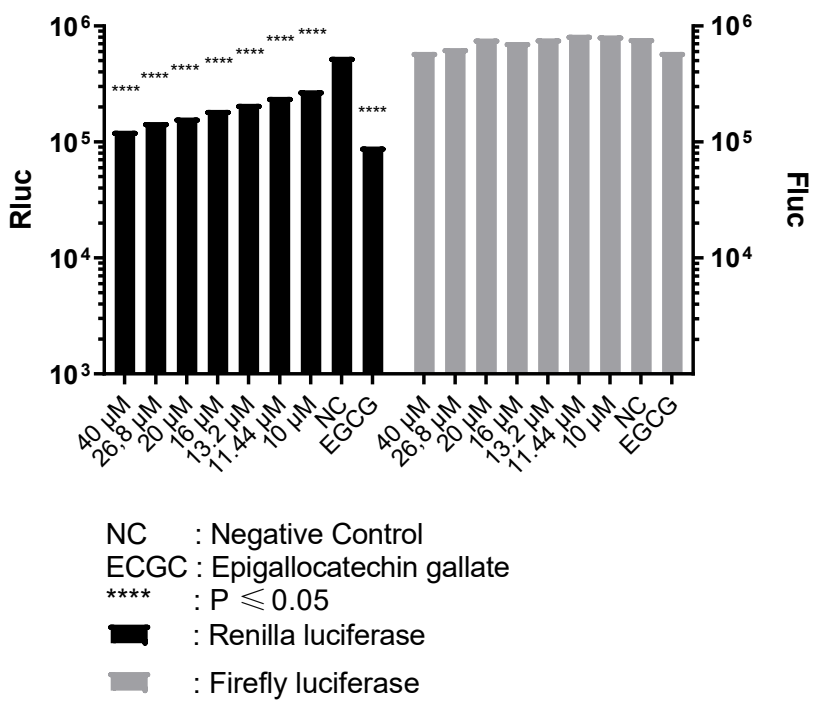

Figure 4. Antiviral activity of rhodatin (1). Huh-7.5 cells were inoculated with RLuc-Jc1 reporter viruses in the presence of rhodatin. Infected cells were lysed 3 days later, and reporter virus infection was determined by renilla luciferase activity (Rluc). The cell viability was measured by determination of firefly luciferase (Fluc), which is stably expressed in the target cells.

In summary, rhodatin (1), a novel meroterpene, with an underlying acorane-type substructure, and rhodocoranes A-E (26), five unusual acorane-type sesquiterpenoids, featuring a novel cyclopentafuranyl-pyranone, were isolated from the wrinkled peach mushroom R. palmatus. Rhodatin (1) may be a promising new candidate in the treatment of HCV in the future. Our results demonstrate that Basidiomycota are still a highly innovative source for new chemistry, ${ }^{16}$ and even the rare species of temperate regions are still by far not exhaustively explored.

\section{ASSOCIA TED CONTENT}

\section{Supporting Information}

The Supporting Information is available free of charge on the ACS Publications website at DOI:

Complete experimental procedures; Biological activity assays; NMR and HRESIMS data, CD spectra (PDF)

\section{Corresponding Author}

* Email: frank.surup@helmholtz-hzi.de.

\section{DIRCII}

Frank Surup: 0000 0001 5234 8525

Marc Stadler: 0000 0002 7284 8671

\section{Present addresses}

| Friedrich-Schiller-University Jena, 07743 Jena, Germany.

\section{Notes}

The authors declare no competing financial interest.

\section{ACKNOWLEDGMENT}

We are much obliged to J. Schnieber (German Mycological Society) for the pictures of $R$. palmatus fruiting bodies. We thank L. Kaysan (TU Ilmenau) for assisting MM with recording optical rotations and UV spectra, C. Chepkirui for valuable scientific discussions, W. Collisi, C. Kakoschke, C. Bergmann, S. Bernecker, R. Sterlinski, and A. Perreth (Helmholtz Centre for Infection Research) for technical support. BS and FS are grateful for support by the German Research Foundation, grant DFG 893/4-1.

\section{REFERENCES}

(1) Redhead, S. A. Can. J. Bot. 1989, 67 (10), 3003-3062.

(2) Sundberg, W. J.; Methven, A. S.; Monoson, H. L. Mycotaxon 1997, 65, 403-410.

(3) European Council for the Conservation of Fungi. Country Reports for the Period 2000-2005.

(4) Suay, I.; Arenal, F.; Asensio, F. J.; Basilio, A.; Cabello, M. A.; Díez, M. T.; García, J. B.; González del Val, A.; Gorrochategui, J.; Hernández, P.; et al. Antonie van Leeuwenhoek, Int. J. Gen. Mol. Microbiol. 2000, 78, 129-139.

(5) Williamson, R. T.; Buevich, A. V.; Martin, G. E.; Parella, T. J. Org. Chem. 2014, 79, 3887-3894.

(6) Hoye, T. R.; Jeffrey, C. S.; Shao, F. Nat. Protoc. 2007, 2, 2451-2458.

(7) Citron, C. A.; Riclea, R.; Brock, N. L.; Dickschat, J. S. RSC Adv. 201 1, 1, 290-297.

(8) Geris, R.; Simpson, T. J. Nat. Prod. Rep. 2009, 26, 1063 1094.

(9) H.M., G.; Y.C., S.; J.R., C.; S., H.; J.Y., W.; R.X., T. Helv. Chim. Acta 2006, 89, 502-506.

(10) World Health Organization. Global Hepatitis Report, 2017.

(11) World Health Organization. Global Health Sector Strategy on Viral Hepatitis 2016-2021, 2016.

(12) Ciesek, S.; von Hahn, T.; Colpitts, C. C.; Schang, L. M.; Friesland, M.; Steinmann, J.; Manns, M. P.; Ott, M.; Wedemeyer, H.; Meuleman, P.; et al. Hepatology 2011, 54, 1947-1955.

(13) Sandargo, B.; Thongbai, B.; Praditya, D.; Steinmann, E.; Stadler, M.; Surup, F. Molecules 2018, 23, 2697.

(14) Miceli, M. H.; Díaz, J. A.; Lee, S. A. Lancet Infect Dis $2011,11,142-151$.

(15) Zaas, A. K.; Boyce, M.; Schell, W.; Lodge, B. A.; Miller, J. L.; Perfect, J. R. J. Clin. Microbiol. 2003, 41, 5233-5235.

(16) Sandargo, B.; Stadler, M.; Chaverra-Muñoz, L.; Chepkirui, C.; Cheng, T.; Thongbai, B.; Hüttel, S. Biotechnol. Adv. 2019, in press, DOI: 10.1016/j.biotechadv.2019.01.011. 
